Wilson, A., and Bolhar, R., 2021, Olivine in komatiite records origin and travel from the deep upper mantle: Geology, https://doi.org/10.1130/G49523.1

\title{
SUPPLEMENTAL DATA
}

\section{OVERVIEW AND GEOLOGICAL SETTING OF THE COMMONDALE KOMATIITES}

The 3.33 Ga Commondale Greenstone Belt (Hoffmann \& Wilson, 2017; Hunter \& Wilson, 1988; Smith, 1987) (Fig. S1) is one of several well-preserved Paleoarchean greenstone fragments located south of the Barberton Greenstone Belt in the Kaapvaal Craton (Hofmann et al., 2019). The Commondale Formation comprises mafic and ultramafic rocks metamorphosed to upper greenschist facies and variably altered to serpentinites (Smith, 1987). The Commondale Ultramafic Suite comprises komatiites located in the core of a synformal structure within low strain that allowed exceptional preservation. Drill cores through this zone provided access to remarkably fresh material, also allowing flow structures to be categorized (Wilson, 2019).

Sedimentary units in the greenstone belt include argillites, fuchsitic cherts, calc-silicate rocks, banded iron formation and ferruginous quartzites (Hunter and Wilson, 1988; Smith, 1987). The interlayering of the ultramafic rocks of the Commondale Formation with banded iron formation indicates a complex interaction of chemical sedimentation and ultramafic/mafic flow deposition.

The komatiites of the Commondale Ultramafic Suite were dated using Sm-Nd isotopes and yielded an age of $3334 \pm 18$ Ma (Wilson and Carlson, 1989). Re-Os dating gave a statistically indistinguishable age of $3393 \pm 440$ Ma (Wilson et al., 2003). Granitoid rocks surrounding the greenstone belt include tonalitic gneisses and less abundant amphibolite intrusions, possibly related to the Ancient Gneiss Complex (AGC) of Swaziland, and are interpreted as pre-greenstone basement. U-Pb zircon dating of tonalitic gneiss yielded an emplacement age of $3419 \pm 7 \mathrm{Ma}$ and a metamorphic age for the same tonalite of $3.21 \mathrm{Ga}$ (Xie et al., 2012).

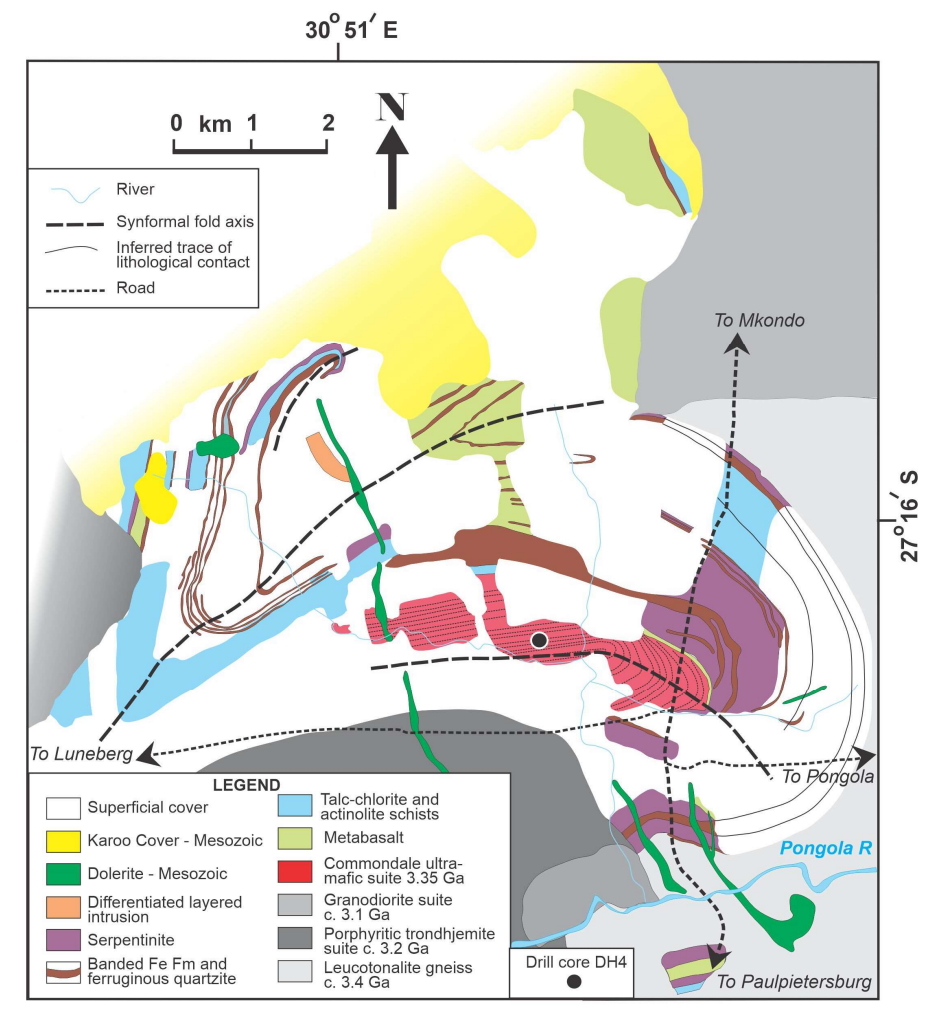


Figure S1. Simplified geological map of the Commondale Greenstone Belt (Hoffmann and Wilson, 2017; Hunter and Wilson, 1988; Smith, 1987). Coordinates of the drill core used in this study UTM Zone $36288436 \mathrm{mE} 6981092 \mathrm{mN}$.

Within the komatiite succession of the Commondale Ultramafic Suite orthopyroxene is abundant both as coarse spinifex units, in association with olivine spinifex, at the top and base of the flow units and commonly as micro-spinifex within the olivine phyric rocks. Clinopyroxene is entirely absent.

The komatiite succession has a minimum thickness of $1.5 \mathrm{~km}$ and is made up of flow units of variable thickness ranging from 1 to $30 \mathrm{~m}$ and, in contrast to most other komatiite occurrences, are not interlayered with or occur in close association with basalts or komatiitic basalts (Wilson, 2019). The make-up of the Commondale komatiite flow units contrasts to most other komatiites in that the chemical distributions of the flows are arranged in a subsymmetrical form pointing to unique physical and chemical controls during eruption of these lavas. Core compositions of olivine of Fo96.2 are the highest measured for any komatiite and attest to the high $\mathrm{MgO}$ content of the parental magma of $36.1 \mathrm{wt} \%$. With a calculated eruption temperature of $1670^{\circ} \mathrm{C}$ these are the highest temperature lavas encountered in Earth's history.

The origin of the Commondale komatiites was initially suggested to be the result of hydrous melting of a depleted and highly refractory mantle wedge (Wilson, 2003) and therefore could have provided evidence for subduction-related processes at this early stage of the Archaean, as was suggested for other komatiites (Parman et al., 2001; Parman et al., 2004). However, the Commondale komatiites do not have subduction (or boninitic) trace element signatures and instead were postulated later to have formed rather by two-stage melting of a mantle plume, albeit at relatively shallow depths (Robin-Popieul et al., 2012). Decoupling between the isotopic systems Nd-Sm and Hf-Lu points to a heterogeneous mantle or an earlier melting event (Hoffmann and Wilson, 2017). Based on recent investigations of high pressure systems (Deng and Stixrude, 2021) bridgmanite crystallization would decouple Hf from Nd. Therefore, melting with bridgmanite in the residue would lead to high $\mathrm{Lu} / \mathrm{Hf}$ ratios in the melt and an unfractionated source for $\mathrm{Sm} / \mathrm{Nd}$ and could represent an even earlier melting event preceding the two-stage melting modelled in this study. Further isotope studies on this class of highly depleted komatiites are warranted.

\section{Alteration and Metamorphism}

As for all komatiites alteration has occurred in the Commondale komatiites and needs to be considered in aspects relating to petrography and geochemistry. The preservation of olivine (including spinifex olivine) in Commondale is remarkable. However, alteration is present to some extent in all samples. Alteration of olivine is to serpentine, magnetite, talc and chlorite and orthopyroxene to chlorite and to tremolite. There is, however, a high degree of preservation of original phases in some parts of the flow sequence. The degree of olivine alteration increases in zones of pervasive foliation. This occurs in the northern fold hinge zone and in the flanks of the synform that contains the komatiite sequence. Although fresh olivine cores are preserved in these more altered zones, tremolite needles are observed to grow into the olivine from the surrounding matrix. Overall, the degree of metamorphism is regarded as being greenschist in the zones studied here increasing to amphibolite grade towards the limbs of the fold structure.

There is no evidence that alteration has affected the zoning in the olivine crystals. In some crystals thin veins of serpentine and magnetite cut right through the zoning pattern without affecting it. Alteration has taken place at the margins of some phyric olivines but this is in contact with an Fe-depleted matrix which has not resulted in reversals of olivine 
composition to higher Fo close to the margins. There is also no evidence that alteration in a third dimension has affected the olivine compositions.

\section{METHODS USED IN THIS STUDY \\ Contamination Assessment}

The possible effects of alteration and contamination from microbeam analysis were carefully considered. This can arise from alteration veins, melt inclusions and other mineral phases enclosed within olivine. The samples used for the study come from drill cores, which intersected the freshest komatiite flows in the Commondale greenstone belt and with olivine grains showing minimal alteration.

All crystals were microscopically examined under high optical power and backscattered electron imagery and were chosen for detailed analysis because of their lack of inclusions and micro-fractures. In Commondale, rare small melt inclusions ( $<10$ microns) have been identified only towards the olivine rims. No inclusions have been identified within olivine cores. Chromite grains are found in the mesostasis and in the margins of some olivine crystals but are extremely rare and none were observed in the regions of detailed analysis. The consistency of most EPMA analyses using a beam of 2-3 microns across individual olivine grains (particularly for $\mathrm{Al}$ and $\mathrm{Cr}$ ) indicates that contamination did not occur during these measurements. Although laser ablation analyses require a larger analytical area the consistency of the EPMA and laser ablation data (Supp. Data 2) indicates that contamination did not present a problem during LA-ICPMS analysis.

\section{Electron microprobe analyses}

Chemical analyses were carried out using the Cameca SX100 electron microprobe at the University of Johannesburg. Primary calibrations were against metal and certified mineral standards. Beam current was $50 \mathrm{nA}$ at $20 \mathrm{kV}$. Analytical run times were adjusted to give maximum precision, particularly for Al. Analytical uncertainties are shown in Supp. Data. 2. Consistency of data was monitored by an in-house olivine standard and the international reference olivine standard MongOl (Batanova et al., 2019). In the latter case the same area in a single grain was analysed repeatedly to avoid possible slight inhomogeneity between grains. Over the course of the study the reference olivine was analysed 20 times registering differences for the elements of interest of $</=2 \%$. Measured $\mathrm{FeO}$ was on average $2 \%$ higher (given as a percentage of the accepted value) than recommended for the reference standard and $\mathrm{MgO} 0.8$ $\%$ lower. The Commondale olivines have much higher $\mathrm{Al}_{2} \mathrm{O}_{3}$ contents than the MongOl standard and the measured value of $0.048 \mathrm{wt} . \% \mathrm{Al}_{2} \mathrm{O}_{3}( \pm 0.003)$ was in agreement with the recommended value of 0.046 wt. $\% \mathrm{Al}_{2} \mathrm{O}_{3}$. Repeated analyses over the duration of the study of a single spot of a Commondale olivine gave an analytical uncertainty of $2.7 \%$ for $\mathrm{Al}_{2} \mathrm{O}_{3}$. Further details are given in Supp. Data 2.

Dr. Christian Reinke is thanked for assistance with the microprobe work.

\section{Laser ablation analyses}

Data for $\mathrm{Al}, \mathrm{Cr}$ and $\mathrm{Ca}$ were verified using laser ablation ICP-MS analyses on several of the same samples as used for the microprobe study. Because of the large beam size (100 microns) details of the zoning could not be investigated by this method. The instruments used were the Australian Scientific Instruments/Applied Spectra Resolution SE $193 \mathrm{~nm}$ ArF excimer laser and the Thermo Scientific Instruments Element XR SF-ICP-MS. Synthetic glass NIST612 was used as primary standard and MongOl-Sh11-2 reference material (Batanova et al., 2019) as secondary, both run repeatedly with the unknown samples. Data reduction was carried out using the Iolite software (Paton et al., 2011). Details of the analytical conditions and results for the reference materials are given in Supp. Data 2. 
Ablation spot size: 100 microns

Ablation time: $50 \mathrm{secs}$ made up of $10 \mathrm{sec}$ pre-ablation, $30 \mathrm{sec}$ ablation, $10 \mathrm{sec}$ post ablation time.

Laser carrier gas: He (350 ml/min), Ar (1000 ml/min), $\mathrm{N}_{2}(5 \mathrm{ml} / \mathrm{min})$

Laser repetition rate: $12 \mathrm{hz}$

Fluence: $4.5 \mathrm{Jcm}^{-2}$

Primary standard: NIST612

Reference standard: MongOl olivine

\section{Mantle melting model}

The mantle melting model is based on the rare earth element composition of the primary Commondale komatiite melt of 36 wt.\% $\mathrm{MgO}$ (Wilson, 2019) with appropriate partition coefficients for mantle phases (wadsleyite-garnet-CaPv) at $16 \mathrm{GPa}$ (McKenzie, 2020; Mibe et al., 2006). Standard melting equations (Shaw, 1970) were employed to produce a residue initially from $40-50 \%$ partial melting of high pressure phases followed by a second stage melt by aggregated fractional melting of the residue to reproduce the observed highly depleted Commondale primary melt.

Phase proportions of the melting events are:

$\mathrm{CaPv}=5 \%$; Garnet $=40 \%$; wadsleyite $=55 \%$

Partition coefficients for wadsleyite and garnet at $16 \mathrm{GPa}$ (Mibe et al., 2006) for the rare earth elements. Partition coefficients for $\mathrm{CaPv}$ (McKenzie, 2020) indicate the affinity for incompatible elements.

Partition coefficients used

$$
\begin{array}{llllllll}
\mathrm{La} & \mathrm{Ce} & \mathrm{Nd} & \mathrm{Sm} & \mathrm{Dy} & \mathrm{Er} & \mathrm{Yb} & \mathrm{Lu}
\end{array}
$$

$\begin{array}{lllllllll}\text { Wadsleyite } & 0.000067 & 0.000021 & 0.000026 & 0.000035 & 0.0002 & 0.00045 & 0.001 & 0.002 \\ \text { Garnet } & 0.0014 & 0.0072 & 0.016 & 0.053 & 0.3 & 0.57 & 0.95 & 1.35 \\ \mathrm{CaPv} & 3 & 3 & 3.1 & 3.5 & 3.8 & 5 & 9 & 9\end{array}$

Melting equations (Shaw, 1970).

Stage 1 melting at $\mathrm{F}=0.4-0.5$

Residue from aggregated fractional melting:

$\mathrm{C}_{\mathrm{s}} / \mathrm{C}_{\mathrm{o}}=(1-\mathrm{F})^{(1 / \mathrm{Do})-1}$

Stage 2 melting at $\mathrm{F}=0.4-0.5$

Fractional melt from depleted residue:

$\mathrm{C}_{1} / \mathrm{C}_{\mathrm{o}}=\left(1 / \mathrm{D}_{\mathrm{o}}\right)(1-\mathrm{F})^{(1 / \mathrm{Do})-1}$

$\mathrm{C}_{\mathrm{s}}=$ concentration of trace element in solid after melting

$\mathrm{C}_{\mathrm{o}}=$ concentration of trace element in initial solid

$\mathrm{C}_{1}=$ concentration of trace element in melt

$\mathrm{F}=$ melt fraction

$\mathrm{D}_{\mathrm{o}}=$ bulk partition coefficient 


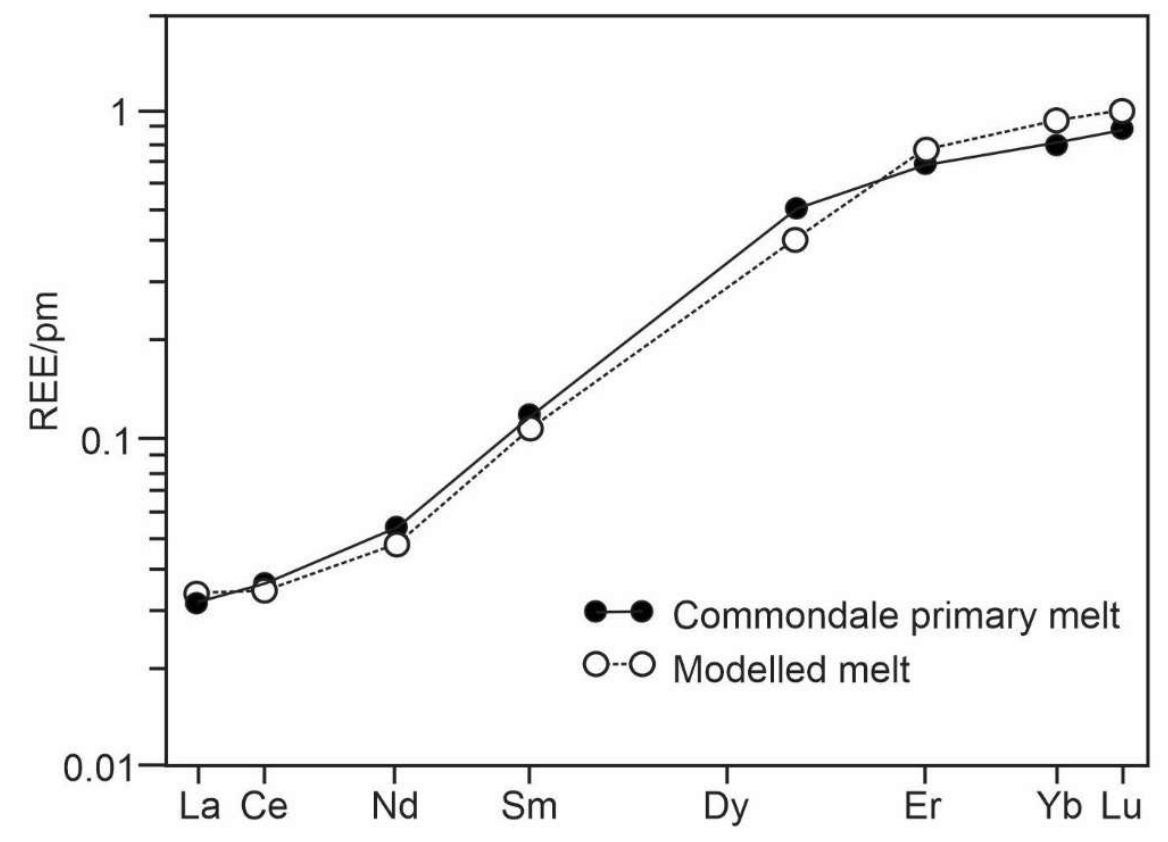

Figure S2. Comparison of Primitive Mantle-normalized REE distributions for the Commondale primary melt (Wilson, 2019) and for the 2-stage melting model. Normalization values from Sun and McDonough (1989).

\section{DISTRIBUTION OF AI AND Cr IN OLIVINE IN COMPARISON TO OTHER PLUME OCCURRENCES}

For many occurrences of plume-derived ultramafic magmas there is strong correlation between $\mathrm{Cr}$ and $\mathrm{Al}$ in olivine with the early Cretaceous komatiites markedly depleted in $\mathrm{Cr}$ (Spice et al., 2016; Trela et al., 2017) compared with those of Archaean age (Fig. S3). The compositions for Archean Alexo, Barberton and Commondale olivines are broadly co-linear with a positive intercept on the $\mathrm{Cr}$ axis. Olivine from Barberton and Alexo komatiites show a spread of Cr values at relatively constant Al. The cause of these differences is currently not known, but may be attributed to a number of controls relating to the mantle source, differences in partition coefficients under different conditions (Taura et al., 1998), changes in the charge balance systematics and site occupancy (Milman-Barris et al., 2008; Taura et al., 1998), and the role of $\mathrm{Cr}^{2+}$ (Hanson and Jones, 1998).

Of importance in this study is that Commondale olivines display striking consistency of data derived by EPMA and laser ablation (Fig. S3), testifying to the reliability and consistency between both analytical methods. Al maxima extend to higher values for the EPMA analyses. This arises because of the lower spatial resolution of the primitive domains in the olivine cores achievable by the broader laser beam (100 microns by LA-ICPMS compared to 2-3 microns for EPMA). 


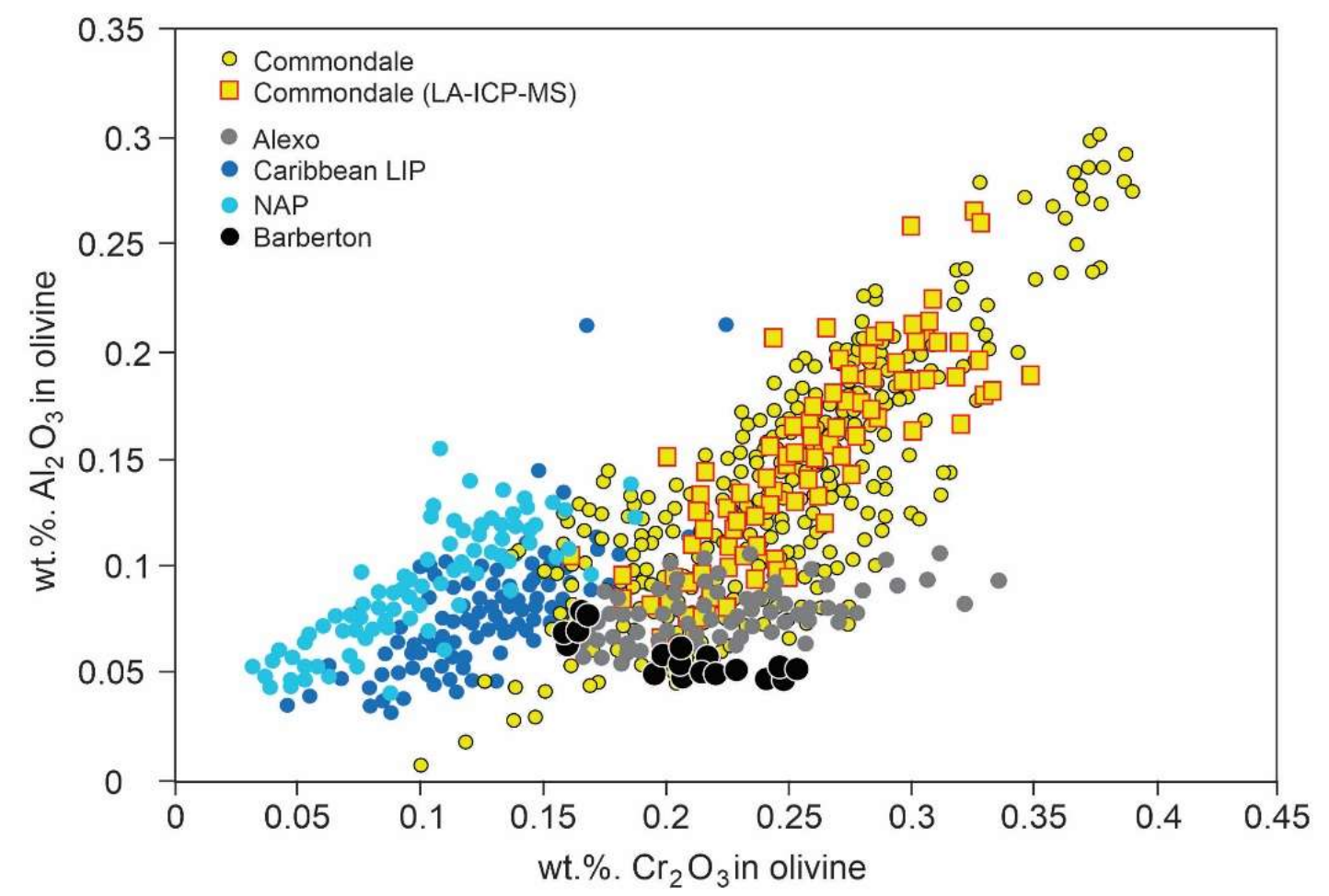

Figure S3. Comparison of Commondale olivine data for $\mathrm{Cr}$ and Al by EPMA and LA-ICPMS. Also shown is the relationship between $\mathrm{Al}$ and $\mathrm{Cr}$ for other komatiites and plumerelated basalts. Data sources; Sobolev et al. (2005), Sobolev et al. (2019), Trela et al. (2017), Spice et al. (2016).

\section{REFERENCES CITED}

Batanova, V. G., Thompson, J. M., Danyushevsky, L. V., Portnyagin, M. V., Garbe-Schonberg, D., Hauri, E., Kimura, J.-I., Chang, Q., Senda, R., Goemann, K., Chauvel, C., Campillo, S., Ionov, D. A. and Sobolev, A. V., 2019, New olivine reference material for in situ microanalysis, Geostandards and Geoanalytical Research, v. 43, p. 453-473.

Deng, J. and Stixrude, L., 2021, Deep fractionation of Hf in a solidifying magma ocean and its implications for tungsten isotopic heterogeneities in the mantle, Earth and Planetary Science Letters, v. 562, no. 116873.

Hanson, B. and Jones, J. H., 1998, The systematics of $\mathrm{Cr}^{3+}$ and $\mathrm{Cr}^{2+}$ partitioning between olivine and liquid in the presence of spinel. American Mineralogist 83, 669-684.

Hoffmann, J. E. and Wilson, A. H., 2017, The origin of highly radiogenic Hf isotopic composition in $3.33 \mathrm{Ga}$ Commondale komatiite lavas (South Africa), Chemical Geology, v. 455, p. 6-21.

Hofmann, A., Anhaeusser, C. R., Dixon, J., Kröner, A., Saha, L., Wilson, A. and Hangqiang, X., 2019, Archaean granitoid-greenstone geology of the southeastern part of the Kaapvaal Craton, in Kröner, A. \& Hofmann, A., eds., The Archaean Geology of the Kaapvaal Craton, Southern Africa: Switzerland, Springer Nature, p. 33-54.

Hunter, D. R. and Wilson, A. H., 1988, A continuous record of Archaean evolution from 3.5 Ga to 2.6 Ga in Swaziland and northern Natal, South African Journal of Geology, v. 91, p. 57-74.

McKenzie, D., 2020, Speculations on the generation and movement of komatiites, Journal of Petrology, v. 61, p. 1-23. 
Mibe, K., Orihashi, Y., Nakai, S. and Fujii, T., 2006, Element partitioning between transitionzone minerals and ultramafic melt under hydrous conditions, Geophysical Research Letters, v. 33.

Milman-Barris, M. S., Beckett, J. R., Baker, M. B., Hofmann, A. E., Morgan, Z., Crowley, M. R., Vielzeuf, D. and Stolper, E., 2008, Zoning of phosphorus in igneous olivine, Contributions to Mineralogy and Petrology, v. 155, p. 739-765.

Parman, S. W., Grove, T. L. and Dann, J. C., 2001, The production of Barberton komatiites in an Archean subduction zone, Geophysical Research Letters 28, 2513-2516.

Parman, S. W., Grove, T. L., Dann, J. C. and de Wit, M. J., 2004, A subduction origin for komatiites and cratonic lithospheric mantle, South African Journal of Geology, v. 107, p. 107-118.

Paton, C., Hellstrom, J., Paul, B., Woodhead, J. and Hergt, J., 2011, Iolite: Freeware for the visualisation and processing of mass spectrometric data. Journal of Analytical Atomic Spectrometry, v. 26, p. 2508-2518.

Robin-Popieul, C. C. M., Arndt, N. T., Chauvel, C., Byerly, G. R., Sobolev, A. V. and Wilson, A. H., 2012, Barberton komatiites produced by deep critical melting with high melt retention, Journal of Petrology, v. 53, p. 2191-2229.

Shaw, D. M., 1970, Trace element fractionation during anatexis, Geochimica et Cosmochimica Acta, v. 34, p. 237-242.

Smith, R. G., 1987, Geochemistry and structure of the Archaean granitoid - supracrustal terrane, southeastern Transvaal and northern Natal, University of Natal, pp. 305.

Sobolev, A. V., Hofmann, A. W., Sobolev, S. V. and Nikogosian, I. K., 2005, An olivine-free mantle source of Hawaiian shield basalts, Nature, v. 434, p. 590-597.

Sobolev, A. V., Asafov, E. V., Gurenko, A. A., Arndt, N. T., Batanova, V. G., Portnyagin, M. V., Garbe-Schönberg, D., Wilson, A. H. and Byerly, G. R., 2019, Deep hydrous mantle reservoir provides evidence for crustal recycling before 3.3 billion years ago, Nature, v. 571, p. 555-559.

Spice, H. E., Fitton, J. G. and Kirstein, L. A., 2016, Temperature fluctuation of the Iceland mantle plume through time, Geochemistry, Geophysics, Geosystems, v. 17, p. 243-254.

Sun, S.-s. and McDonough, W. F., 1989, Chemical and isotopic systematics of oceanic basalts: implications for mantle composition and processes, in Saunders, A. D. and Norry, M. J., eds., Magmatism in the Ocean Basins: London, Geological Society of London, p. 313-345.

Taura, H., Yurimoto, H., Kurita, K. and Sueno, S., 1998, Pressure dependence on partition coefficients for trace elements between olivine and the coexisting melts, Physics and Chemistry of Minerals, v. 25, p. 469-484.

Trela, J., Gazel, E., Sobolev, A. V., Moore, L., Bizimis, M., Jicha, B. and Batanova, V. G., 2017, The hottest lavas of the Phanerozoic and the survival of deep Archaean reservoirs, Nature Geoscience, v. 10, p. 451-456.

Wilson, A. H., 2003, A new class of silica enriched, highly depleted komatiites in the southern Kaapvaal Craton, South Africa, Precambrian Research, v. 127, p. 125-141.

Wilson, A. H., 2019, The late-Paleoarchean ultra-depleted Commondale komatiites: Earth's hottest lavas and consequences for eruption, Journal of Petrology, v. 60, p. 1575-1620.

Wilson, A. H. \& Carlson, R. W., 1989, A Sm-Nd and Pb-Pb isotopic study of Archaean greenstone belts in the southern Kaapvaal Craton, South Africa, Earth and Planetary Science Letters, v. 96, p. 89-105.

Wilson, A. H., Shirey, S. B. \& Carlson, R. W., 2003, Archaean ultra-depleted komatiites formed by hydrous melting of cratonic mantle, Nature, v. 423, p. 858-861. 
Xie, H., Hofmann, A., Hegner, E., Wilson, A. H., Wan, Y. and Liu, D., 2012, Zircon SHRIMP dating confirms a Palaeoarchaean supracrustal terrain in the southeastern Kaapvaal Craton, South Africa, Gondwana Research, v. 21, p. 818-828. 